\title{
ANALISIS PENDAPATAN PETANI CABAI RAWIT MITRA PT TUNAS AGRO PERSADA SAYUNG KABUPATEN DEMAK
}

\section{INCOME ANALYSIS OF BIRD'S EYE CHILIES PARTNERS OF PT TUNAS AGRO PERSADA SAYUNG, DEMAK REGENCY}

\author{
Dicky Denira Daru Putra ${ }^{1 *}$ \\ ${ }^{1}$ Fakultas Peternakan dan Pertanian Universitas Diponegoro \\ Email : putradhenira@gmail.com
}

\begin{abstract}
ABSTRAK
PT Tunas Agro Persada merupakan perusahaan yang bergerak dalam bidang pertanian salah satunya budidaya tanaman cabai. Budidaya cabai ini dijadikan sebagai sumber pendapatan bagi perusahaan. Tujuan penelitian adalah untuk menganalisis pendapatan cabai rawit dan menganalisis faktor-faktor yang mempengaruhi pendapatan petani cabai rawit mitra PT Tunas Agro Persada Sayung Kabupaten Demak. Penelitian dilakukan pada Bulan Desember 2020 pada petani cabai rawit mitra PT Tunas Agro Persada Sayung Demak di Kecamatan Suruh Kota Salatiga dengan pertimbangan perusahaan memiliki potensi budidaya dan penjualan cabai dengan sekala besar. Jumlah petani mitra sebanyak 36 orang petani dengan total luas lahan sebesar 7,85 hektar. Metode penelitian ini menggunakan metode penelitian sensus. Analisis data yang digunakan dalam penelitian yaitu pendapatan, profitabilitas, dan analisis regresi linear berganda. Hasil menunjukkan bahwa rata-rata pendapatan petani sebesar Rp 47.850.344/musim dan profitabilitas sebesar $201,48 \%$, artinya kegiatan budidaya cabai rawit yang dijalankan sangat layak dan sangat menguntungkan. Secara serempak variabel jumlah produksi, biaya tenaga kerja, biaya pemupukan, dan biaya pestisida berpengaruh signifikan terhadap pendapatan cabai rawit. Secara parsial jumlah produksi dan biaya pemupukan berpengaruh signifikan terhadap pendapatan cabai rawit, sedangkan biaya tenaga kerja dan biaya pestisida tidak berpengaruh signifikan. Penggunaan faktor produksi tenaga kerja, pupuk, dan pestisida perlu dikurangi jumlahnya hingga mencapai jumlah penggunaan yang optimal agar menekan pengeluaran biaya yang berlebih dan dapat meningkatkan pendapatan kegiatan budidaya cabai rawit.
\end{abstract}

Kata kunci : cabai rawit, faktor-faktor, pendapatan, profitabilitas.

\section{ABSTRACT}

PT Tunas Agro Persada is a company engaged in agriculture, which one is chili cultivation. This chili cultivation is used as a source of company income. This research was aimed to analyze the income of bird's eye chilies and to analyze the factors that influence the income of bird's eye chilies partners of PT Tunas Agro Persada Sayung, Demak Regency. The research was conducted in December 2020 on bird's eye chilies farmers partner PT Tunas Agro Persada Sayung Demak in Suruh District, Salatiga City, with the consideration that it has the potential to cultivate and trade chilies on a large scale. The number of partner farmers is 36 farmers with a total land area of 7.85 hectares. Sencus method was used in this research. Income, profitability, and multiple linear regression analysis was used in this research. The results showed that the average farmer's income was Rp 47,850,344/season and the profitability was $201,48 \%$, meaning that the bird's eye chilies cultivation is very feasible and very profitable. Simultaneously the variables of production quantities, labor costs, fertilizer costs, and pesticide costs had a significant effect on bird's eye chilies income. Partially the production quantities and fertilizer costs had a significant effect on bird's eye chilies income, while labor costs and pesticide costs do not have a significant effect. The use of labors, fertilizers, and pesticides production factors needs to be 


\section{ANALISIS PENDAPATAN PETANI CABAI RAWIT MITRA PT TUNAS AGRO PERSADA SAYUNG KABUPATEN DEMAK \\ Dicky Denira Daru Putra}

reduced to reach the optimal amount of use in order to reduce excessive costs and increase income for bird's eye chilies cultivation.

Keywords : bird's eye chilies, factors, income, profitability.

\section{PENDAHULUAN}

Cabai (Capsicum frutescens L.) merupakan salah satu tanaman hortikultura dari famili Solanaceae yang memiliki nilai ekonomi tinggi (Cahyono, 2003). Cabai termasuk salah satu tanaman sayuran penting dalam kehidupan sehari-hari bagi masyarakat di Indonesia. Keunggulan lain cabai selain sebagai penyedap rasa masakan, juga sebagai sumber vitamin (vitamin A, B1, dan C), protein, karbohidrat, lemak, kalsium, fosfor, dan besi, serta mengandung senyawa koloid, capsaicin, flavonoid, dan minyak esensial. Cabai berfungsi juga sebagai pembersih paruparu, pengobatan bronchitis, masuk angin, sinusitis, influenza, reumatik, dan asma (Setiadi, 2006).

Masyarakat Indonesia selama ini mengenal tiga jenis cabai, yakni cabai merah besar, cabai rawit, dan cabai merah keriting. Menurut Sunarjono (2009) ada dua golongan tanaman cabai yang terkenal, yaitu cabai besar dan cabai kecil. Cabai yang termasuk dalam golongan cabai kecil ialah cabai rawit. Sebagian besar penduduk Indonesia mengonsumsi cabai dalam bentuk segar, kering, atau olahan. Cabai termasuk komoditas unggulan nasional dan sebagai sumber vitamin C (Waliyanti, 2017).
Cabai rawit adalah salah satu komoditi sayur yang sangat dibutuhkan oleh hampir semua orang dari berbagai lapisan masyarakat (Rostini, 2011). Cabai rawit memiliki ukuran lebih kecil dari pada varietas cabai lainnya, cabai rawit dianggap cukup pedas karena kepedasannya mencapai 225.000 325.000 pada skala scoville. Kebutuhan akan cabai rawit terus meningkat setiap tahun sejalan dengan meningkatnya jumlah penduduk dan berkembangnya industri yang membutuhkan bahan baku cabai rawit (Ardian et al., 2017).

Produktivitas cabai rawit di Indonesia pada tahun 2019 menurut data Kementerian Pertanian (2020) masih tergolong rendah sebesar 8,23 ton/ha, sedangkan potensi produksinya dapat mencapai 20 ton/ha. Berdasarkan hal itu, maka usaha peningkatan produksi cabai dapat dilakukan dengan cara perbaikan teknik budidaya yang meliputi pemupukan dengan pupuk organik dan penggunaan varietas cabai yang digunakan. Produksi cabai rawit nasional dalam kurun waktu 2015-2019 selalu mengalami peningkatan dengan jumlah produksi pada tahun 2019 sebesar 1,374 juta ton dan meningkat sebesar $2,89 \%$ dibandingkan jumlah produksi tahun 2018 (Kementerian Pertanian, 2020). 
Berdasarkan data Kementerian Pertanian (2020) dapat diketahui bahwa produksi cabai rawit setiap tahunnya mengalami peningkatan. Adapun peningkatan produksi cabai rawit di Indonesia dikontribusi oleh daerah sentra-sentra penghasil cabai rawit seperti: Jawa Timur, NTB, Jawa Tengah, Jawa Barat, dan Aceh. Jumlah produksi cabai rawit di Jawa Tengah pada tahun 2019 sebesar 148.750 ton dengan luas panen mencapai 23.892 ha. Produksi cabai rawit di Jawa Tengah mengalami peningkatan dari tahun 2018 sebesar 4,92\% namun mengalami penurunan luas panen dari tahun 2018 sebesar $1,21 \%$.

Kendala yang paling umum
dialami oleh petani kecil dalam
melakukan kegiatan budidaya usahatani cabai rawit adalah pelaksanaan kegiatan budidaya secara sederhana, teknologi produksi dilakukan secara turun menurun, dan terbatasnya modal usaha (Baru et al., 2015; Sondakh dan Rengku, 2017; Wahyuni dan Djuwendah, 2018; Sofa et al., 2020). Usaha budidaya tanaman cabai ini belum berorientasi ekonomi sehingga tidak memperhitungkan biaya-biaya yang dikeluarkan selama proses produksi serta pendapatan yang diperoleh. Penggunaan biaya sarana produksi dan biaya lainnya belum banyak dikaji secara bisnis dalam kegiatan budidaya yang dilakukan oleh petani kecil.
Pengembangan kegiatan usahatani yang berorientasi pada keuntungan bertujuan untuk peningkatan kemampuan dan keterampilan petani dalam melaksanakan kegiatan usahataninya. PT Tunas Agro Persada kemudian bermitra kepada sejumlah petani di Kecamatan Suruh Kota Salatiga agar kegiatan usahatani cabai rawit dapat tumbuh dan berkembang dengan menuntut kegiatan usahatani yang berorientasi kepada keuntungan. PT Tunas Agro Persada merupakan perusahaan yang bergerak dibidang benih, pupuk organik, dan mulsa melihat potensi pengembangan budidaya cabai rawit di Jawa Tengah. PT Tunas Agro Persada ini memiliki potensi budidaya dan penjualan cabai dengan sekala besar yang kemudian didistribusikan ke berbagai wilayah di Jawa Tengah.

Analisis perhitungan dilakukan untuk memberikan gambaran mengenai produksi dan harga jual yang pada akhirnya akan berpengaruh terhadap pendapatan petani dalam berusahatani cabai. Usahatani cabai skalanya relatif kecil dan adanya ketergantungan terhadap harga jual yang selalu berfluktuasi setiap waktu akan mempengaruhi hasil usahatani serta pendapatan petani. Tinggi rendahnya pendapatan suatu usaha budidaya tanaman cabai rawit dipengaruhi oleh sejumlah faktor seperti jumlah produksi, biaya tenaga kerja, biaya pupuk organik, 


\section{ANALISIS PENDAPATAN PETANI CABAI RAWIT MITRA PT TUNAS AGRO PERSADA SAYUNG KABUPATEN DEMAK \\ Dicky Denira Daru Putra}

biaya pupuk kimia, dan biaya pestisida. Berdasarkan kondisi tersebut maka diperlukan adanya analisis pendapatan komoditas tanaman cabai rawit pada petani mitra PT Tunas Agro Persada Sayung, Demak.

Tujuan dari penelitian adalah untuk menganalisis pendapatan petani cabai rawit mitra PT Tunas Agro Persada Sayung Kabupaten Demak dan menganalisis faktor-faktor yang mempengaruhi pendapatan petani cabai rawit mitra PT Tunas Agro Persada Sayung Kabupaten Demak.

\section{METODE PENELITIAN}

Penelitian dilakukan pada Bulan Desember 2020 pada petani cabai rawit mitra PT Tunas Agro Persada Sayung Demak. Penentuan lokasi penelitian ini dilakukan secara purposive. Menurut Sugiyono (2011) purposive adalah teknik penentuan lokasi penelitian berdasarkan pertimbangan bahwa di PT Tunas Agro Persada ini memiliki potensi budidaya dan penjualan cabai dengan sekala besar, cabai tersebut di kirim berbagai wilayah Jawa Tengah. Lahan budidaya cabai ini berlokasi di Kecamatan Suruh Kota Salatiga yang bermitra dengan 36 orang petani dengan total luas lahan sebesar 7,85 hektar.

Metode penelitian ini menggunakan metode sensus. Penelitian sensus merupakan penelitian yang mengambil satu kelompok populasi sebagai sampel secara keseluruhan dan menggunakan kuesioner yang terstruktur sebagai alat pengumpulan data yang pokok untuk mendapatkan infromasi yang spesifik (Sugiyono, 2011). Kelompok populasi yang diamati dalam penelitian ini adalah seluruh petani cabai rawit mitra PT Tunas Agro Persada Sayung, Demak sebanyak 36 petani.

\section{Analisis Pendapatan}

Analisis data dalam penelitian ini menggunakan perhitungan biaya produksi, penerimaan, dan pendapatan yang di gunakan sebagai berikut :

1. Biaya produksi adalah keseluruhan biaya perolehan input untuk menghasilkan output. Rumus perhitungan biaya produksi adalah sebagai berikut (Kuswadi, 2006).

$$
\mathrm{TC}=\mathrm{TFC}+\mathrm{TVC}
$$

Keterangan :

$\mathrm{TC}=$ Total Biaya Produksi

TFC $=$ Total Biaya Tetap

TVC $=$ Total Biaya Variabel

Komponen biaya tetap dalam penelitian ini terdiri atas biaya penyusutan dan biaya sewa lahan. Rumus perhitungan penyusutan adalah sebagai berikut (Kuswadi, 2006).

Penyusutan $=\frac{\text { Nilai Awal-Nilai Akhir }}{\text { Umur Ekonomis }}$

2. Penerimaan adalah seluruh hasil yang diterima dari penjualan produk pada harga tertentu. Rumus 
perhitungan penerimaan adalah sebagai berikut (Kuswadi, 2006).

$$
\mathrm{TR}=\mathrm{Q} \times \mathrm{P}
$$

Keterangan :

TR $=$ Total Penerimaan

$Q$ = Jumlah Produksi

$\mathrm{P}=$ Harga Produksi

3. Pendapatan adalah perbedaan/selisih antara total penerimaan dengan total biaya tetap. Rumus perhitungan pendapatan adalah sebagai berikut (Kuswadi, 2006).

$$
\text { Pendapatan }=\mathrm{TR}-\mathrm{TC}
$$

Keterangan :

$\mathrm{TR}=$ Total Penerimaan

$\mathrm{TC}=$ Total Biaya Produksi

4. Probabilitas adalah harga angka yang menunjukkan seberapa besar kemungkinan suatu peristiwa terjadi, di antara keseluruhan peristiwa yang mungkin terjadi. Rumus perhitungan pendapatan adalah sebagai berikut (Ambarsari et al., 2014).

Profitabilitas $=\frac{\text { Pendapatan }}{\text { Biaya } \text { Produksi }} \times 100 \%$

Kriteria yang diajukan adalah sebagai berikut:

- Usaha dikatakan layak dan menguntungkan apabila nilai profitabilitas > suku bunga deposito bank (Bank BRI Bulan Januari 2021 = $3,5 \%)$.

- Usaha dikatakan tidak layak dan tidak menguntungkan apabila nilai profitabilitas $\leq$ suku bunga deposito bank (Bank BRI Bulan Januari $2021=$ $3,5 \%)$.

\section{Analisis Regresi Linear Berganda}

Analisis regresi linear berganda digunakan untuk mengetahui pengaruh jumlah produksi, biaya tenaga kerja, biaya pemupukan, dan biaya pestisida terhadap jumlah pendapatan cabai rawit di PT Tunas Agro Persada. Model regresi yang diajukan dalam penelitian ini sebagai berikut :

$$
\begin{aligned}
& Y=a+b_{1} X_{1}+b_{2} X_{2}+b_{3} X_{3}+b_{4} X_{4}+e \\
& \mathrm{Y} \quad=\text { Jumlah pendapatan (Rp/musim) } \\
& \text { a } \quad \text { Konstanta } \\
& b_{1}-b_{4}=\text { Koefisien regresi masing- } \\
& \text { masing variabel } \\
& \mathrm{X}_{1}=\text { Produksi (Kg/musim) } \\
& \mathrm{X}_{2}=\text { Biaya tenaga kerja }(\mathrm{Rp} / \mathrm{musim}) \\
& \mathrm{X}_{3}=\text { Biaya pemupukan (Rp/musim) } \\
& \mathrm{X}_{4} \quad=\text { Biaya pestisida (Rp/musim) } \\
& \mathrm{e} \quad=\text { Error term (tingkat kesalahan) }
\end{aligned}
$$

\section{Koefisien Determinasi $\left(\mathbf{R}^{2}\right)$.}

Koefisien determinasi digunakan untuk mengukur seberapa jauh kemampuan model dalam menerangkan variasi variabel dependen. Nilai koefisien determinasi adalah antara nol dan satu (Ghozali, 2011). Nilai yang kecil berarti kemampuan variabel independen dalam menjelaskan variabel dependen sangat terbatas. Nilai yang mendekati satu berarti variabel independen memberikan hampir semua informasi untuk memprediksi variabel dependen (Saefuddin et al., 2010). 


\section{ANALISIS PENDAPATAN PETANI CABAI RAWIT MITRA PT TUNAS AGRO PERSADA SAYUNG KABUPATEN DEMAK \\ Dicky Denira Daru Putra}

\section{Uji Simultan (Uji F).}

Uji ini digunakan untuk mengetahui apakah semua variabel independen yang dimasukkan dalam model mempunyai pengaruh secara bersama-sama (simultan) terhadap variabel dependen (Widarjono, 2010). Hipotesis yang diajukan adalah (Suharyadi dan Purwanto, 2011):

- $\mathrm{H}_{0}: b_{1}=b_{2}=b_{3}=b_{4}=0$; Secara serempak jumlah produksi, biaya tenaga kerja, biaya pemupukan, dan biaya pestisida tidak mempengaruhi pendapatan cabai rawit di PT Tunas Agro Persada Sayung, Demak.

- $H_{1}: b_{1} \neq b_{2} \neq b_{3} \neq b_{4} \neq 0$; Secara serempak jumlah produksi, biaya tenaga kerja, biaya pemupukan, dan biaya pestisida mempengaruhi pendapatan cabai rawit di PT Tunas Agro Persada Sayung, Demak.

Kriteria pengujiannya adalah:

- $\mathrm{H}_{0}$ diterima dan $\mathrm{H}_{\mathrm{I}}$ ditolak apabila nilai $F_{\text {hitung }} \leq F_{\text {tabel }}$ atau nilai Sig. $>0,05$.

- $\mathrm{H}_{0}$ ditolak dan $\mathrm{H}_{\mathrm{I}}$ diterima apabila nilai $F_{\text {hitung }}>F_{\text {tabel }}$ atau nilai Sig. $\leq 0,05$.

Uji Parsial (Uji t).

Uji t digunakan untuk mengetahui seberapa jauh pengaruh dari sejumlah variabel independen $(X)$ secara parsial dalam menerangkan variasi variabel dependen (Y) (Saefuddin et al., 2010). Hipotesis yang diajukan adalah (Suharyadi dan Purwanto, 2011):
- $\mathrm{H}_{0}: \mathrm{b} 1=0 ; \mathrm{b} 2=0 ; \mathrm{b} 3=0 ; \mathrm{b} 4=0$; Jumlah produksi, biaya tenaga kerja, biaya pemupukan, dan biaya pestisida secara parsial tidak mempengaruhi pendapatan cabai rawit di PT Tunas Agro Persada Sayung, Demak.

- $\mathrm{H}_{1}$ : b1 $\neq 0$; b2 $\neq 0$; b3 $\neq 0$; b4 $\neq 0$; Jumlah produksi, biaya tenaga kerja, biaya pemupukan, dan biaya pestisida secara parsial mempengaruhi pendapatan cabai rawit di PT Tunas Agro Persada Sayung, Demak.

Kriteria pengujiannya adalah:

- $\mathrm{H}_{0}$ diterima dan $\mathrm{H}_{1}$ ditolak apabila nilai $t_{\text {hitung }} \leq t_{\text {tabel }}$ atau nilai Sig. $>0,05$.

- $\mathrm{H}_{0}$ ditolak dan $\mathrm{H}_{\mathrm{I}}$ diterima apabila nilai $t_{\text {hitung }}>t_{\text {tabel }}$ atau nilai Sig. $\leq 0,05$.

\section{HASIL DAN PEMBAHASAN}

\section{Identitas Responden}

Berdasarkan hasil pengumpulan data primer dengan menggunakan kuesioner yang dibagikan kepada responden, dapat diketahui hasil gambaran umum yang ditinjau dari kategori usia, pendidikan, luas lahan, dan lama responden berusahatani cabai rawit disajikan pada Tabel 1.

Berdasarkan Tabel 1 dapat diketahui bahwa mayoritas usia responden petani cabai rawit mitra di Kecamatan Suruh memiliki rentang usia 36-50 tahun sebanyak 16 responden atau $44,4 \%$. Hal ini menunjukkan bahwa ratarata petani cabai rawit berada pada usia produktif. Usia produktif untuk bekerja 
menurut BPS (2014) berada pada rentang usia 15 - 64 tahun. Usia produktif merupakan usia sesorang dikatakan

Tabel 1. Identitas Responden

\begin{tabular}{|c|c|c|c|}
\hline No & Kategori & Jumlah & Persentase \\
\hline & & --- Jiwa --- & ---- \% ---- \\
\hline \multirow[t]{4}{*}{1} & Usia (Tahun) & & \\
\hline & $24-35$ & 9 & 25,0 \\
\hline & $36-50$ & 16 & 44,4 \\
\hline & $52-62$ & 11 & 30,6 \\
\hline \multirow[t]{4}{*}{2} & Tingkat Pendidikan & & \\
\hline & Tamat SD & 23 & 63,9 \\
\hline & Tamat SMP & 8 & 22,2 \\
\hline & Tamat SMA & 5 & 13,9 \\
\hline \multirow[t]{4}{*}{3} & Luas Lahan $\left(\mathrm{m}^{2}\right)$ & & \\
\hline & $<2000$ & 11 & 30,6 \\
\hline & $2000-2500$ & 18 & 50,0 \\
\hline & $>2500$ & 7 & 19,4 \\
\hline \multirow[t]{4}{*}{4} & Pengalaman (Tahun) & & \\
\hline & $1-5$ & 13 & 36,1 \\
\hline & $6-10$ & 11 & 30,6 \\
\hline & $11-30$ & 12 & 33,3 \\
\hline
\end{tabular}

Berdasarkan Tabel 1 diketahui bahwa tingkat pendidikan responden didominasi oleh lulusan Sekolah Dasar (SD) sebanyak 23 responden $(63,9$ persen). Petani dengan pendidikan yang lebih rendah membuat penyerapan informasi relatif lebih lambat, sehingga mempengaruhi keterampilan yang dimiliki. Hasil ini sesuai dengan pernyataan Suryani et al. (2017) yang mengatakan bahwa tingkat pendidikan menentukan perilaku seseorang dan mempengaruhi pertimbangan rasional dalam menerima informasi.

Berdasarkan Tabel 1 diketahui bahwa luas lahan garapan petani responden terbilang sempit. Hal ini ditunjukkan oleh 19,4 persen. petani responden yang memiliki luas lahan mampu untuk bekerja dan memperoleh penghasilan dari pekerjaannya. 


\section{ANALISIS PENDAPATAN PETANI CABAI RAWIT MITRA PT TUNAS AGRO PERSADA \\ SAYUNG KABUPATEN DEMAK}

Dicky Denira Daru Putra

kegiatan usahatani lebih mampu mengatasi permasalahan yang dihadapi dalam melakukan usahanya karena memiliki pengetahuan dan keterampilan yang lebih. Hal ini sesuai dengan pernyataan Batoa et al. (2008) yang menyatakan bahwa pengalamam berusahatani pada umumnya dapat meningkatkan keterampilan dan menambah pengetahuan petani di bandingkan dengan petani yang masih memiliki sedikit pengalaman.

\section{Biaya Produksi}

Biaya produksi merupakan sejumlah uang yang timbul dan digunakan untuk dapat menghasilkan suatu produk. Biaya produksi dapat meliputi biaya bahan baku, biaya tenaga kerja, biaya overhead, dan lain sebagainya. Menurut Widjajanta et al. (2007), biaya produksi merupakan keseluruhan dari faktor produksi yang dikorbankan dalam proses produksi untuk menghasilkan suatu produk dalam suatu perusahaan. Rincian rata-rata biaya produksi disajikan pada Tabel 2.

Tabel 2. Rata-rata Biaya Produksi Budidaya Cabai Rawit Per Musim

\begin{tabular}{|c|c|c|c|}
\hline \multirow{2}{*}{ Rincian Biaya } & \multicolumn{2}{|c|}{ Jumlah } & \multirow{2}{*}{ Persentase } \\
\hline & Satuan & Nilai & \\
\hline & & ---- Rp ---- & $--\%$ \\
\hline \multicolumn{4}{|l|}{ Biaya Tetap } \\
\hline Sewa Lahan & & 1.490 .047 & 6,23 \\
\hline Penyusutan & & 331.620 & 1,39 \\
\hline Total Biaya Tetap & & 1.821 .667 & \\
\hline \multicolumn{4}{|l|}{ Biaya Variabel } \\
\hline Benih & $3.395 \mathrm{pcs}$ & 128.264 & 0,54 \\
\hline \multicolumn{4}{|l|}{ Tenaga Kerja } \\
\hline Pengolahan Lahan & $22 \mathrm{HOK}$ & 1.713 .218 & \\
\hline Perawatan & $19 \mathrm{HOK}$ & 2.225 .994 & \\
\hline Panen & $22 \mathrm{HOK}$ & 1.151 .131 & \\
\hline Total Biaya Tenaga & & 5.090 .343 & 21,28 \\
\hline $\begin{array}{l}\text { Kerja } \\
\text { Aiir }\end{array}$ & & 2.138 .178 & 8,94 \\
\hline Ajir & $\begin{array}{r}4.527 \text { batang } \\
3 \text { roll }\end{array}$ & 2.791 .111 & $\begin{array}{r}0,94 \\
11,67\end{array}$ \\
\hline Mulsa & 3 roll & & $\begin{array}{r}1,01 \\
200\end{array}$ \\
\hline \multirow{2}{*}{\multicolumn{4}{|c|}{ Pupuk }} \\
\hline & & & \\
\hline Pupuk Kandang & 141 sak & 2.160 .072 & \\
\hline Urea & $124 \mathrm{~kg}$ & 359.197 & \\
\hline Za & $26 \mathrm{~kg}$ & 51.205 & \\
\hline Phonska & $110 \mathrm{~kg}$ & 1.150 .684 & \\
\hline Dolomit & $434 \mathrm{~kg}$ & 224.167 & \\
\hline Total Biaya Pupuk & & 3.945 .326 & 16,49 \\
\hline \multicolumn{4}{|l|}{ Pestisida } \\
\hline Fungisida & $4.372 \mathrm{ml}$ & 1.366 .287 & \\
\hline Insektisida & $3.472 \mathrm{ml}$ & 4.750 .027 & \\
\hline Obat Gulma & $542 \mathrm{ml}$ & 30.283 & \\
\hline Total Biaya Pestisida & & 6.146 .597 & 25,70 \\
\hline Lain-lain & & 1.380 .799 & 5,77 \\
\hline Total Biaya Variabel & & 22.098 .887 & \\
\hline Total Biaya Produksi & & 23.920 .553 & 100,00 \\
\hline
\end{tabular}


Berdasarkan hasil penelitian diketahui bahwa rata-rata luas lahan petani mitra sebesar $2.180,56 \mathrm{~m}^{2}$. Biaya produksi yang disajikan pada Tabel 2 merupakan rata-rata biaya produksi budidaya cabai rawit yang dibutuhkan dengan rata-rata luas lahan sebesar $2.180,56 \mathrm{~m}^{2}$. Biaya produksi budidaya cabai rawit digolongkan menjadi dua, yaitu biaya tetap dan biaya variabel. Biaya tetap adalah keseluruhan biaya yang dikeluarkan untuk memperoleh faktor produksi (input) yang tidak dapat diubah jumlahnya. Menurut Widjajanta et al. (2007) biaya tetap adalah biaya yang jumlahnya tetap atau tidak berubah dalam rentang waktu tertentu berapapun besarnya produksi. Biaya variabel adalah keseluruhan biaya yang dikeluarkan untuk memperoleh faktor produksi yang dapat diubah jumlahnya. Menurut Soekartawi et al. (2011) biaya variabel adalah biaya yang dalam rentang waktu dan sampai batas-batas tertentu jumlahnya berubah-ubah secara proporsional.

Berdasarkan Tabel 2 diketahui bahwa rata-rata total biaya produksi yang diperlukan per petani dalam satu musim tanam dengan rata-rata luas lahan sebesar 2.180,56 $\mathrm{m}^{2}$ adalah sebesar Rp 23.920.553. Komponen utama biaya produksi terdiri atas biaya tetap dan biaya variabel. Biaya tetap terdiri atas biaya sewa lahan dan biaya penyusutan. Biaya variabel terdiri atas biaya benih, biaya tenaga kerja, ajir, mulsa, penjepit mulsa, biaya pupuk, biaya pestisida, dan biaya lainnya. Rata-rata total biaya tetap adalah sebesar Rp 1.821 .667 yang terdiri dari rata-rata biaya sewa lahan sebesar Rp 1.490.047 dan rata-rata biaya penyusutan sebesar Rp 331.620. Jumlah biaya tetap yang dikeluarkan tidak dipengaruhi oleh kapasitas produksi. Hal ini sesuai dengan pernyataan Widjajanta et al. (2007) bahwa total biaya tetap jumlahnya tetap dan tidak berubah berapapun besarnya produksi.

Rata-rata total biaya variabel yang dikeluarkan per petani per musim dengan rata-rata luas lahan sebesar $2.180,56 \mathrm{~m}^{2}$ berdasarkan Tabel 2 adalah sebesar Rp 22.098.887 yang terdiri atas biaya benih, biaya tenaga kerja, ajir, mulsa, penjepit mulsa, biaya pupuk, biaya pestisida, dan biaya lainnya. Rata-rata jumlah benih yang dibutuhkan per musim tanam sebanyak 3.395 pcs dengan biaya sebesar Rp 128.264. Benih merupakan salah satu input yang cukup vital karena akan mempengaruhi keberhasilan produktivitas tanaman cabai rawit. Menurut Prajnanta (2011) biaya benih adalah korbanan paling penting yang dikeluarkan sebelum memulai budidaya cabai rawit karena yang nantinya akan menghasilkan cabai rawit untuk dipanen. Berdasarkan Tabel 2 biaya tenaga kerja terdiri atas biaya tenaga kerja pengolahan 


\section{ANALISIS PENDAPATAN PETANI CABAI RAWIT MITRA PT TUNAS AGRO PERSADA SAYUNG KABUPATEN DEMAK \\ Dicky Denira Daru Putra}

lahan, biaya tenaga kerja perawatan, dan biaya tenaga kerja panen. Rata-rata total biaya tenaga kerja per petani per musim dengan rata-rata luas lahan sebesar 2.180,56 $\mathrm{m}^{2}$ adalah sebesar $\mathrm{Rp}$ 5.090 .343 yang terdiri dari rata-rata biaya tenaga kerja pengolahan lahan per musim sebesar Rp 1.713.218 dengan jumlah rata-rata $22 \mathrm{HOK}$, rata-rata biaya tenaga kerja perawatan per musim sebesar Rp 2.225.994 dengan rata-rata 19 HOK, dan rata-rata biaya tenaga kerja panen sebesar Rp 1.151.131 dengan rata-rata 22 HOK. Tenaga kerja merupakan salah satu unsur penentu dalam keberhasilan kegiatan usahatani. Menurut Suratiyah (2006) tenaga kerja dalam kegiatan pertanian memiliki peranan penting karena fungsinya belum bisa sepenuhnya digantikan oleh teknologi.

Tabel 2 menampilkan rata-rata jumlah ajir yang dibutuhkan per petani per musim tanam dengan rata-rata luas lahan sebesar 2.180,56 $\mathrm{m}^{2}$ sebanyak 4.527 batang dengan rata-rata biaya yang dibutuhkan per musim sebesar Rp 2.138.178. Ajir pada tanaman cabai rawit berfungsi sebagai penopang tanaman agar tidak mudah goyah, roboh, dan rebah. Ajir sangat berguna Ketika kondisi cuaca ekstrem yang dapat merusak tanaman cabai rawit seperti hujan lebat dan tiupan angin kencang. Menurut Mulyani (2020) kegunaan ajir pada tanaman cabai sebagai penopang tanaman agar tidak rebah, batang tanaman dapat tumbuh lurus, memaksimalkan pertumbuhan tanaman, dan mengoptimalkan proses fotosintesis karena posisi tanaman yang tegak ke atas.

Rata-rata penggunaan mulsa per musim tanam dengan rata-rata luas lahan sebesar 2.180,56 $\mathrm{m}^{2}$ berdasarkan Tabel 5 adalah sebanyak 3 roll dengan rata-rata biaya yang dikeluarkan per petani per musim tanam adalah sebesar $\mathrm{Rp}$ 2.791.111. Mulsa merupakan lembaran plastik yang akan menutupi zona lahan pada tanaman yang bertujuan menjaga dan melindungi permukaan tanah dari pengikisan, menjaga kelembaban, dan menghalangi perkembangan hama gulma. Menurut Mulyani (2020) mulsa berfungsi sebagai pelindung tanah dari daya rusak butir hujan, mengikat penyerapan air oleh tanah, mengurangi erosi, menjaga kelembaban tanah, dan mengendalikan pertumbuhan gulma. Penggunaan mulsa diikuti oleh penggunaan penjepit mulsa. Rata-rata penggunaan penjepit mulsa per musim tanam sebanyak 13 pak dengan rata-rata biaya yang dikeluarkan per musim tanam dengan rata-rata luas lahan sebesar 2.180,56 $\mathrm{m}^{2}$ sebesar $\mathrm{Rp}$ 478.269. Penjepit mulsa diperlukan agar mulsa dapat terpasang sempurna dan berfungsi secara optimal. 
Berdasarkan Tabel 2 diketahui bahwa rata-rata total biaya pupuk dengan rata-rata luas lahan sebesar 2.180,56 $\mathrm{m}^{2}$ adalah sebesar Rp 3.945.326. Biaya pupuk terdiri atas pupuk kandang, urea, Za, phonska, dan dolomit. Rata-rata kebutuhan pupuk kandang per musim tanam sebanyak 141 sak berukuran $50 \mathrm{~kg}$ dengan rata-rata biaya yang dikeluarkan per musim sebesar Rp 2.160.072. Ratarata kebutuhan urea per musim tanam sebanyak $124 \mathrm{~kg}$ dengan rata-rata biaya yang dikeluarkan sebesar Rp 359.197. Rata-rata kebutuhan Za per musim tanam sebanyak $26 \mathrm{~kg}$ dengan rata-rata biaya yang dikeluarkan, sebesar Rp 51.205.

Rata-rata kebutuhan phonska per musim tanam sebanyak $110 \mathrm{~kg}$ dengan rata-rata biaya yang dikeluarkan sebesar Rp 1.150.684. Rata-rata kebutuhan dolomit per musim tanam sebanyak $434 \mathrm{~kg}$ dengan rata-rata biaya yang dikeluarkan sebesar Rp 224.167. Pemupukan bertujuan untuk melengkapi penyediaan hara yang ada dalam tanah untuk memenuhi kebutuhan tanaman cabai rawit. Menurut Prajnanta (2011), pemupukan merupakan komponen teknologi yang sangat mempengaruhi hasil bagi petani cabai karena berfungsi sebagai penyedia hara tambahan bagi tanaman yang tidak dapat dipenuhi oleh tanah.

Tabel 2 menampilkan rata-rata total biaya pestisida yang dibutuhkan per musim tanam dengan rata-rata luas lahan sebesar 2.180,56 $\mathrm{m}^{2}$ adalah sebesar $\mathrm{Rp}$ 6.146.597 yang terdiri atas biaya fungisida, insektisida, dan obat gulma. Rata-rata kebutuhan fungisida per musim tanam adalah sebanyak $4.372 \mathrm{ml}$ dengan rata-rata biaya yang dibutuhkan per musim tanam sebesar Rp 1.366.287. Rata-rata kebutuhan insektisida per musim tanam adalah sebanyak $3.472 \mathrm{ml}$ dengan rata-rata biaya yang dibutuhkan per musim tanam sebesar $\operatorname{Rp} 4.750 .027$. Rata-rata kebutuhan obat gulma per musim tanam adalah sebanyak $542 \mathrm{ml}$ dengan rata-rata biaya yang dibutuhkan per musim tanam sebesar Rp 30.283. Pemberian pestisida bertujuan untuk pengendalian hama, jamur, dan gulma yang menyerang tanaman cabai rawit. Dosis pemberian pestisida bergantung pada frekuensi serangan dan jumlah serangan terhadap tanaman cabai rawit. Menurut Mulyani (2020) pemberian pestisida dapat dilakukan sebagai pencegahan atau penyembuhan tanaman dari organisme pengganggu tanaman. Pestisida terdiri dari insektisida untuk memberantas hama serangga, fungisida untuk memberantas cendawan penyakit, dan obat gulma untuk memberantas gulma di sekitar tanaman cabai rawit.

Biaya lain-lain yang dikeluarkan berdasarkan Tabel 2 terdiri atas biaya bahan bakar, biaya pengairan, biaya 


\section{ANALISIS PENDAPATAN PETANI CABAI RAWIT MITRA PT TUNAS AGRO PERSADA SAYUNG KABUPATEN DEMAK \\ Dicky Denira Daru Putra}

listrik, dan sejumlah biaya tidak terduga lainnya. Rata-rata biaya lain-lain yang dikeluarkan per musim tanam dengan rata-rata luas lahan sebesar 2.180,56 $\mathrm{m}^{2}$ sebesar Rp 1.380 .799 (5,77\%). Biaya lain-lain adalah komponen biaya yang tidak secara langsung dapat mempengaruhi kegiatan budidaya ataupun produksi namun tetap perlu diperhitungkan.

Tabel 3. Produksi, Penerimaan, dan Pendapatan Budidaya Cabai Rawit

\begin{tabular}{lc}
\hline \hline \multicolumn{1}{c}{ Keterangan } & Rata-rata Per Petani Per Musim \\
\hline Produksi & $2.392,36 \mathrm{~kg}$ \\
Penerimaan & $\mathrm{Rp} 71.770 .897$ \\
Total Biaya Produksi & $\mathrm{Rp} 23.920 .553$ \\
Pendapatan & $\mathrm{Rp} 47.850 .344$ \\
\hline
\end{tabular}

Produksi, Penerimaan, dan Pendapatan

Cabai rawit yang siap panen kemudian langsung dijual kepada PT Tunas Agro Persada dengan menetapkan harga beli rawit terhadap petani mitra sebesar Rp 30.000 per kilogram. Cabai rawit yang dibeli adalah yang memiliki kualitas baik dan sudah sesuai standar yang ditetapkan. Buah cabai rawit yang baik adalah cabai rawit yang sudah cukup tua, padat, berisi, dan berwarna hijau kemerahan atau oranye. Rincian rata-rata jumlah produksi, penerimaan, dan pendapatan disajikan pada Tabel 3.

Berdasarkan Tabel 3 diketahui bahwa rata-rata produksi cabai rawit per petani dalam satu musim dengan ratarata luas lahan sebesar $2.180,56 \mathrm{~m}^{2}$ adalah sebanyak $2.392,36 \mathrm{~kg}$. Harga jual cabai rawit yang ditetapkan oleh PT Tunas Agro Persada adalah sebesar Rp 30.000 per kg, sehingga rata-rata jumlah penerimaan per petani dalam satu musim tanam adalah sebesar Rp 71.770.897.
Produksi adalah jumlah hasil panen cabai rawit. Penerimaan diperoleh dari jumlah produksi yang dikalikan dengan harga jual. Jumlah produksi yang tinggi maka jumlah penerimaan yang diperoleh akan tinggi dan sebaliknya jumlah produksi rendah maka penerimaan yang diperoleh juga rendah. Hal ini sesuai dengan pendapat Widjajanta et al. (2007) yang menyatakan bahwa faktor yang mempengaruhi besar kecilnya jumlah penerimaan pada petani yaitu jumlah produksi. Petani yang memperoleh produksi tinggi akan mendapatkan penerimaan yang besar dan petani yang memperoleh penerimaan kecil maka penerimaan yang diterima juga kecil.

Tabel 3 menampilkan rata-rata total biaya produksi per petani per musim tanam dengan rata-rata luas lahan sebesar 2.180,56 $\mathrm{m}^{2}$ adalah sebesar Rp 23.920.553, sehingga rata-rata pendapatan per petani per musim tanam dengan rata-rata luas lahan sebesar 2.180,56 $\mathrm{m}^{2}$ adalah sebesar $\mathrm{Rp}$ 
47.850.344. Total biaya produksi adalah biaya korbanan yang dikeluarkan dalam melakukan kegiatan usahatani. Pendapatan diperoleh dari nilai penerimaan yang dikurangi oleh total biaya produksi. Menurut Aulia (2008) pendapatan merupakan laba bersih yang di terima petani dari hasil usahataninya dengan mengurangkan penerimaan dengan biaya yang di keluarkan selama proses produksi. Jumlah pendapatan yang diterima oleh setiap petani berbedabeda. Hal ini dapat dipengaruhi oleh tersedianya modal dan tenaga kerja. Modal yang banyak akan mampu mempekerjakan tenaga kerja yang ahli sehingga dapat meningkatkan hasil produksi dan dapat menghasilkan produk yang berkualitas. Faisal (2015) menyatakan bahwa faktor yang mempengaruhi pendapatan yaitu skala usaha, tersedianya modal, tingkat harga output, tersedianya tenaga kerja, sarana transportasi, dan sistem pemasaran.

\section{Profitabilitas}

Analisis profitabilitas diperlukan untuk mengetahui laba yang diperoleh dalam usahanya dan analisis profitabilitas juga dapat digunakan sebagai alat ukur untuk mengetahui perkembangan usaha yang sedang dijalankan. Profitabilitas dapat dihitung dengan perbandingan antara pendapatan dengan biaya produksi dikalikan 100 persen. Rincian komponen analisis profitabilitas disajikan pada Tabel 4.

Tabel 4. Rata-rata Profitabilitas Budidaya Cabai Rawit Petani Mitra Periode 2018-2020

\begin{tabular}{|c|c|c|c|}
\hline Keterangan & Pendapatan & Biaya Produksi & Profitabilitas \\
\hline & \multicolumn{2}{|c|}{------- Rp ------- } & ----- \% ----- \\
\hline Cabai Rawit & 430.653 .099 & 215.284 .979 & 201,48 \\
\hline
\end{tabular}

Berdasarkan Tabel 4 diketahui bahwa profitabilitas budidaya cabai rawit sebesar 201,48 persen. Hasil ini menunjukkan bahwa kegiatan budidaya cabai rawit yang dijalankan sangat layak dan sangat menguntungkan. Profitabilitas dikatakan layak apabila nilainya lebih tinggi dibandingkan dengan suku bunga bank deposito. Suku bunga bank deposito Bank BRI pada Bulan Januari 2021 adalah sebesar 3,5 persen. Hasil ini sesuai dengan pendapat Ambarsari et al.
(2014) bahwa apabila hasil perhitungan profitabilitas lebih dari suku bunga bank deposito makan usaha tersebut dapat dikatakan layak dan sebaliknya apabila hasil perhitungan profitabilitas kurang dari suku bunga bank deposito maka usaha tersebut dikatakan tidak layak.

\section{Persamaan Regresi}

Analisis regresi linear berganda pada penelitian ini digunakan untuk menguji pengaruh variabel-variabel independen yaitu produksi, biaya tenaga 


\section{ANALISIS PENDAPATAN PETANI CABAI RAWIT MITRA PT TUNAS AGRO PERSADA SAYUNG KABUPATEN DEMAK \\ Dicky Denira Daru Putra}

kerja, biaya pupuk, dan biaya pestisida terhadap pendapatan budidaya cabai rawit. Hasil analisis regresi linier berganda disajikan pada Tabel 5.

Tabel 5. Hasil Analisis Regresi Linear Berganda

\begin{tabular}{|c|c|c|c|c|}
\hline \multirow{2}{*}{ Variabel } & \multicolumn{2}{|c|}{ Unstandardized Coefficients } & \multirow{2}{*}{$\mathrm{t}$} & \multirow{2}{*}{ Sig. } \\
\hline & $B$ & Std. Error & & \\
\hline (Constant) & 2.296 .000 & 480.020 & 4,783 & 0,000 \\
\hline Produksi & $19.587,272$ & 145,582 & 134,545 & $0,000^{*}$ \\
\hline $\begin{array}{l}\text { Biaya Tenaga } \\
\text { Kerja }\end{array}$ & $-0,073$ & 0,056 & $-1,312$ & 0,199 \\
\hline Biaya Pupuk & $-0,188$ & 0,085 & $-2,220$ & $0,034^{*}$ \\
\hline Biaya Pestisida & $-0,031$ & 0,039 & $-0,805$ & 0,427 \\
\hline $\begin{array}{l}\text { R Square } \\
\text { Adjusted R Square }\end{array}$ & $\begin{array}{l}0,999 \\
0,999\end{array}$ & & & \\
\hline $\begin{array}{l}\mathrm{F} \\
\text { Sig. }\end{array}$ & $\begin{array}{l}7.786 \\
0,000\end{array}$ & & & \\
\hline
\end{tabular}

Keterangan: *signifikan 0,05.

Berdasarkan Tabel 10 dapat diketahui bahwa persamaan regresi yang terbentuk adalah sebagai berikut:

$$
\begin{aligned}
& Y=2.296 .000+19.587,272 \times 1- \\
& 0,073 \times 2-0,188 \times 3-0,031 \times 4+e \\
& \text { Nilai koefisien setiap variabel }
\end{aligned}
$$
yang diperoleh menunjukkan hubungan antara variabel bebas dengan variabel terikat. Nilai koefisien variabel positif menunjukkan apabila terjadi peningkatan satu nilai pada variabel bebas maka variabel terikat akan mengalami peningkatan sebesar nilai koefisien variabel bebas tersebut dan berlaku kelipatannya, sebaliknya apabila nilai koefisien variabel negatif menunjukkan apabila terjadi peningkatan satu nilai pada variabel bebas maka variabel terikat akan mengalami penurunan sebesar nilai koefisien variabel bebas tersebut.

Berdasarkan persamaan regresi yang sudah terbentuk diketahui apabila keempat variabel bebas bernilai 0 maka pendapatan cabai rawit per musim akan bernilai sebesar nilai a yaitu $R p$ 2.296.000. Setiap peningkatan produksi cabai rawit sebesar $1 \mathrm{~kg}$ akan meningkatkan pendapatan sebesar Rp 19.587 per musim tanam. Setiap peningkatan biaya tenaga kerja sebesar Rp 1.000 akan menurunkan pendapatan sebesar Rp 73 per musim tanam. Setiap peningkatan biaya pupuk sebesar Rp 1.000 maka akan menurunkan pendapatan sebesar Rp 188 per musim tanam. Setiap peningkatan biaya pestisida sebesar Rp 1.000 maka akan menurunkan pendapatan sebesar Rp 31 per musim tanam.

\section{Hasil Koefisien Determinasi}

Koefisien determinasi bertujuan untuk melihat seberapa besar variabel bebas yang diajukan dalam penelitian mampu menjelaskan variabel terikat. Hasil penelitian menunjukkan bahwa nilai Adjusted R-Square yaitu sebesar 0,999. 
Hasil ini menunjukkan bahwa variabel bebas (produksi, biaya tenaga kerja, biaya pupuk, dan biaya pestisida) mampu menjelaskan variabel terikat (pendapatan cabai rawit) sebesar 99,9 persen. dan sisanya sebesar 0,01 persen. dijelaskan oleh faktor-faktor lain di luar model yang diajukan. Hal ini menunjukkan bahwa pemilihan variabel dalam penelitian sudah baik karena memiliki nilai koefisien determinasi yang mendekati 1. Nilai koefisien determinasi dikatakan baik jika nilainya semakin mendekati 1. Hal ini sesuai dengan pernyataan Sugiyono (2011) yang menyebutkan bahwa dalam analisis koefisien determinasi, nilai $R$ square dikatakan baik jika bernilai diatas 0,5 dan semakin mendekati 1 . Artinya variabel bebas yang diajukan dalam model penelitian semakin dapat menjelaskan variabel terikat secara baik.

\section{Hasil Uji F}

Tabel 5 menampilkan hasil uji $\mathrm{F}$ menunjukkan nilai signifikansi hitung sebesar $0,000 \leq 0,05$ sehingga $\mathrm{H}_{0}$ ditolak dan $\mathrm{H}_{1}$ diterima, artinya secara serempak seluruh variabel bebas (produksi, biaya tenaga kerja, biaya pupuk, dan biaya pestisida) berpengaruh nyata terhadap model regresi yang diajukan dan merupakan penjelas yang signifikan terhadap variabel terikat (pendapatan). Hasil ini sesuai dengan pernyataan Suharyadi dan Purwanto (2011) yang menyatakan bahwa apabila nilai Sig. $\leq$ nilai a $(0,05)$ maka $H_{0}$ ditolak dan $H_{1}$ diterima, maka seluruh variabel bebas secara bersama-sama (simultan) mempengaruhi variabel terikat.

\section{Hasil Uji t}

Berdasarkan Tabel 5 dapat diketahui bahwa nilai signifikansi hitung pada variabel produksi adalah sebesar $0,000 \leq 0,05$, maka $H_{0}$ ditolak dan $H_{1}$ diterima. Artinya secara parsial produksi berpengaruh secara parsial terhadap pendapatan cabai rawit. Nilai koefisien regresi yang bernilai positif menunjukkan bahwa peningkatan jumlah produksi akan meningkatkan pendapatan secara signifikan. Hasil ini menunjukkan bahwa jumlah pendapatan yang diterima dipengaruhi oleh jumlah produksi yang dihasilkan. Semakin tinggi jumlah produksi cabai rawit, semakin tinggi pula pendapatan yang diterima. Sebaliknya, penurunan jumlah produksi cabai rawit menyebabkan penurunan pendapatan yang diterima. Hal ini sesuai dengan pernyataan Faisal (2015) yang menyatakan bahwa faktor yang mempengaruhi pendapatan yaitu jumlah produksi dan tingkat harga output.

Hasil nilai signifikansi hitung variabel biaya tenaga kerja berdasarkan Tabel 5 menunjukkan hasil 0,199 >0,05, maka $\mathrm{H}_{0}$ diterima dan $\mathrm{H}_{l}$ ditolak. Artinya secara parsial biaya tenaga kerja tidak berpengaruh secara parsial terhadap pendapatan cabai rawit. Nilai koefisien 


\section{ANALISIS PENDAPATAN PETANI CABAI RAWIT MITRA PT TUNAS AGRO PERSADA SAYUNG KABUPATEN DEMAK \\ Dicky Denira Daru Putra}

regresi yang bernilai negatif menunjukkan bahwa peningkatan biaya tenaga kerja yang dikeluarkan akan menurunkan pendapatan. Hal ini menunjukkan bahwa penggunaan tenaga kerja telah melebihi kebutuhan optimalnya, yang menyebabkan biaya tenaga kerja menjadi semakin tinggi. Hasil ini sejalan dengan penelitian Sondakh dan Rengku (2017) yang menunjukkan bahwa biaya tenaga kerja tidak berpengaruh secara signifikan terhadap pendapatan usahatani. Nilai koefisien regresi yang bernilai negatif menunjukkan bahwa peningkatan biaya tenaga kerja akan menurunkan pendapatan usahatani.

Tabel 5 menunjukkan bahwa nilai signifikansi hitung variabel biaya pupuk sebesar $0,034 \leq 0,05$, maka $\mathrm{H}_{0}$ ditolak dan $H_{1}$ diterima. Artinya secara parsial biaya pupuk berpengaruh secara parsial terhadap pendapatan cabai rawit. Nilai koefisien regresi yang bernilai negatif menunjukkan bahwa peningkatan biaya pupuk yang dikeluarkan akan menurunkan pendapatan secara signifikan. Hal ini menunjukkan bahwa penggunaan pupuk telah melebihi kebutuhan optimalnya, yang menyebabkan biaya pupuk menjadi semakin tinggi. Hasil ini sejalan dengan penelitian Sondakh dan Rengku (2017) yang menunjukkan bahwa biaya pupuk berpengaruh secara signifikan terhadap pendapatan usahatani. Nilai koefisien regresi yang bernilai negatif menunjukkan bahwa peningkatan biaya pupuk akan menurunkan pendapatan usahatani.

$$
\text { Berdasarkan Tabel } 5
$$
menunjukkan bahwa nilai signifikansi hitung variabel biaya pestisida sebesar $0,427>0,05$, maka $\mathrm{H}_{0}$ diterima dan $\mathrm{H}_{1}$ ditolak. Artinya secara parsial biaya pestisida tidak berpengaruh secara parsial terhadap pendapatan cabai rawit. Nilai koefisien regresi yang bernilai negatif menunjukkan bahwa peningkatan biaya pestisida yang dikeluarkan akan menurunkan pendapatan. Hal ini menunjukkan bahwa penggunaan pestisida telah melebihi kebutuhan optimalnya, yang menyebabkan biaya pestisida menjadi semakin tinggi. Hasil ini sejalan dengan penelitian Sondakh dan Rengku (2017) yang menunjukkan bahwa biaya pestisida tidak berpengaruh secara signifikan terhadap pendapatan usahatani. Nilai koefisien regresi yang bernilai negatif menunjukkan bahwa peningkatan biaya pestisida akan menurunkan pendapatan usahatani.

\section{KESIMPULAN}

Berdasarkan hasil penelitian dapat disimpulkan bahwa:

1. Rata-rata pendapatan petani cabai rawit mitra PT Tunas Agro Persada pada periode 2018-2020 sebesar Rp 430.653.099 dan rata-rata pendapatan petani per musim tanam sebesar Rp 47.850.344 dengan rata-rata luas 
lahan petani mitra sebesar $2.180,56$ $\mathrm{m}^{2}$. Nilai profitabilitas sebesar 201,48 persen, yang menunjukkan bahwa kegiatan budidaya cabai rawit yang dijalankan sangat layak dan sangat menguntungkan.

2. Secara serempak variabel produksi, biaya tenaga kerja, biaya pupuk, dan biaya pestisida berpengaruh signifikan terhadap pendapatan budidaya cabai rawit. Secara parsial variabel produksi dan biaya pupuk berpengaruh secara signifikan terhadap pendapatan budidaya cabai rawit, sedangkan variabel biaya tenaga kerja dan biaya pestisida tidak berpengaruh secara signifikan terhadap pendapatan budidaya cabai rawit.

\section{DAFTAR PUSTAKA}

Ambarsari, W., V. D. Y. B Ismadi, dan A. Setiadi. 2014. Analisis pendapatan dan profitabilitas usahatani padi (Oryza sativa) di Kabupaten Indramayu. J. Agri Wiralodra. 6(2) : 19-27.

Ardian, R., W. Sudarta, dan I. K. Rantau. 2017. Perbandingan pendapatan usahatani cabai rawit dengan menggunakan pupuk anorganik dan pupuk campuran(organik, dan anorganik) (studi kasus di Subak Kudungan, Desa Bontihing, Kecamatan Kubutambahan, Kabupaten Buleleng). J. Agribisnis dan Agrowisata. 6(2) : 240-248.

Aulia, A.N. 2008. Analisis Pendapatan Usahatani Padi dan Kelayakan Usahatani Vanili pada Ketinggian Lahan 350-800 m dpl di Kabupaten Tasikmalaya. Program Sarjana Institut Pertanian Bogor, Bogor.
(Skripsi Studi Ekonomi Pertanian dan Sumberdaya).

Baru, H. G., D. Tariningsih, dan I. M. Tamba. 2015. Analisis pendapatan usahatani cabai di Desa Antapan (studi kasus di Desa Antapan, Kecamatan Baturiti, Kabupaten Tabanan). J. Agrimeta, 5(10) : 1420.

Batoa, H., A. Jahi, dan D. Susanto. Faktor-faktor yang berhubungan dengan kompetensi petani rumput laut di Kabupaten Konawe Provinsi Sulawesi Tenggara. J. Penyuluhan. 4(1) : 30-38.

Cahyono, B. 2003. Cabai Rawit. Kanisius, Yogyakarta.

Faisal, H. N. 2015. Analisis pendapatan usahatani dan saluran pemasaran pepaya (Carica papaya L) di Kabupaten Tulungagung (studi kasus di Desa Bangoan, Kecamatan Kedunwaru, Kabupaten Tulungagung). J. Agribisnis Fakultas Pertanian Unita. 11(13) : 12-28.

Ghozali, I. 2011. Aplikasi Analisis Multivariate dengan program SPSS. Grasindo, Yogyakarta.

Kementerian Pertanian. 2020. Data Lima Tahun Terakhir Sub-Sektor Hortikultura.

https://www.pertanian.go.id/home/? show $=$ page \&act $=$ view $\& i d=61$ Diakses pada 24 Januari 2021.

Kuswadi. 2006. Memahami Rasio-Rasio Keuangan bagi Orang Awam. PT Elex Media Komputindo, Jakarta.

Mulyani, S. 2020. Praktis dan Mudah Menanam Cabai di Rumah. Bhuana IImu Populer, Jakarta.

Prajnanta, F. 2011. Mengatasi Permasalahan Bertanam Cabai. Penebar Swadaya, Jakarta.

Rostini, N. 2011. 6 Jurus Bertanam Cabai Bebas Hama \& Penyakit. Agromedia, Jakarta. 


\section{ANALISIS PENDAPATAN PETANI CABAI RAWIT MITRA PT TUNAS AGRO PERSADA \\ SAYUNG KABUPATEN DEMAK}

Dicky Denira Daru Putra

Saefuddin, A., K. A. Natodiputro, A. Alamudi, dan K. Sadik. 2010. Statistika Dasar. Grasindo, Yogyakarta.

Setiadi, Y. 2006. Cabai Rawit Jenis dan Budaya. Penebar Swadaya, Jakarta.

Soekartawi, A. Soebarjo, J. Dillon, dan J. B. Hardaker. 2011. Ilmu Usahatani dan Penelitian untuk Pengembangan Petani Kecil Cetakan Ketiga. Penerbit Universitas Indonesia, Jakarta.

Sofa, M. F., Saparto, dan Sumardi. 2020. Analisis pendapatan dan kelayakan usahatani cabai rawit di Desa Kesambi Kecamatan Mejobo Kabupaten Kudus. J. Agromedia. 38(1) : 45-49.

Sondakh, N. dan J. O. Rengku. 2017. Faktor-faktor yang memengaruhi peningkatan pendapatan usahatani cabai rawit di Kabupaten Minahasa Selatan. J. Bisnis dan Kewirausahaan. 13(2) : 74-86.

Sugiyono. 2011. Metode Penelitian Kuantitatif, Kualitatif dan R\&D. Afabeta, Bandung.

Suharyadi dan Purwanto. 2011. Statistika untuk Ekonomi dan Keuangan Modern. Saalemba Empat, Jakarta.

Sunarjono, H. 2009. Bertanam 30 Jenis Sayur. Penebar Swadaya, Jakarta.

Suratiyah, K. 2015. IImu Usahatani (Edisi Revisi). Penebar Swadaya, Jakarta.
Suryani, A., A. Fatchiya, dan D. Susanto. 2017. Keberlanjutan penerapan teknologi pengelolaan pekarangan oleh wanita tani di Kabupaten Kuningan. J. Penyuluhan. 13(1) : 50-63.

Susilowati, S. H. dan M. Maulana. 2012. Luas lahan usahatani dan kesejahteraan petani : eksistensi petani gurem dan urgensi kebijakan reforma agraria. J. Analisis Kebijakan Pertanian. 10(1) : 17-30.

Wahyuni, D. W. dan E. Djuwendah. 2018. Analisis pendapatan dan faktorfaktor yang mempengaruhi produktivitas cabai rawit pada kelompok mitra tani Desa Mandalahaji Kecamatan Pacet. J. IImu Pertanian dan Peternakan. 6(2) : 93-103.

Waliyanti, N. I. 2017. Analisis Supply Demand Komoditas Cabai Merah Besar dan Cabai Rawit (Studi Kasus Pasar Tradisional Kota Makassar). Skripsi Sarjana Pertanian. Universitas Hasanuddin, Makassar.

Widarjono, A. 2010. Analisis Statistika Multivariate Terapan. UPP STIM YKPN, Yogyakarta.

Widjajanta, B., A. Widyaningsih, dan $\mathrm{H}$. Tanuatmodjo. 2007. Mengasah Kemampuan Ekonomi. CV Citra Praya, Bandung. 